\title{
Feed Supplementation with Encapsulated Indigenous Probiotic Lactic Acid Bacteria Increased Broiler Chicken Performance
}

\author{
Monica Sonia Indri Pradipta ${ }^{1}$, Sri-Harimurti ${ }^{1}$, and Widodo ${ }^{1}$, \\ ${ }^{1}$ Faculty of Animal Science, Universitas Gadjah Mada, Bulaksumur, Yogyakarta 55281, Indonesia \\ *Corresponding author: widodohs@ugm.ac.id
}

\author{
KEYWORDS \\ Broiler performance \\ Microencapsulation \\ Poultry \\ Probiotics
}

\begin{abstract}
The oral application of probiotics in the poultry industry is time-consuming and laborious. Therefore, using a powdered probiotic supplement that can easily mix with feed is important. We investigated the effect of spray drying encapsulation on the viability of indigenous probiotic lactic acid bacteria during production and storage and evaluated broiler chicken performance after providing the supplement. Encapsulated probiotics exhibited $>80 \%$ survival rates after spray drying. All bacterial species maintained up to $80 \%$ cell viability rates after exposure to $80-85^{\circ} \mathrm{C}$ temperatures for 15 or $30 \mathrm{~s}$. The viable cell number of all encapsulated bacteria decreased over seven weeks of storage. The supplement was mixed with feed at concentrations 0.5 (T1), 1.0 (T2), and 1.5 (T3) g/ kg feed and administered to 48 one-day-old Lohmann broiler chickens for 21 days; a T0 group was raised without probiotic supplementation. Probiotic supplementation affected body weight gain, live weight, and feed conversion ratio. The cecum length and duodenum and cecum weights significantly differed among the treatment groups. Probiotic supplementation was associated with improved villus development in the intestinal epithelium compared with that of the control. Thus, feed supplementation with indigenous probiotic powder stimulates intestinal epithelial proliferation in broiler chickens during the starter phase, improving their performance.
\end{abstract}

(c) The Author(s) 2019. This article is distributed under a Creative Commons Attribution-ShareAlike 4.0 International license.

\section{INTRODUCTION}

The addition of antibiotics in poultry feed has been banned in the European Union (Cogliani et al. 2011), because of concerns regarding increased antibiotic resistance among microorganisms and the accumulation of antibiotic residues in food. Probiotics are thus promoted as an alternative to antibiotics. Probiotics contain one or more strains of microorganisms, and when powdered, can be used as an animal feed supplement (Fuller 1992). Lactic acid bacteria (LAB) is the most commonly used probiotic agent in poultry production. A previous study showed that, when mixed with poultry feed, LAB replaced pathogens via competitive exclusion (Harimurti 2009; van Immerseel et al. 2009; Arsi et al. 2015; Schneitz et al. 2016). In another study that used probiotics as an efficient replacement of antibiotic growth promoters, an increase in intestinal length and liver and gizzard weights along with a decrease in abdominal fat was reported (Harimurti and Hadisaputro 2014). The oral supplementation of broiler chickens with LAB probiotics at dosages as high as 107, 108, and 109 colony-forming units (CFUs) $/ \mathrm{mL} /$ bird/day increased the total LAB population in the gastrointestinal tract, as well as the villus height and width and crypt depth, thereby improving the performance of chickens (Harimurti et al. 2012, 2013). Thus, these observations show that LAB of poultry origin are ideal probiotics for broiler chickens. Effectiveness and efficiency are the most important factors in oral probiotic supplementation because individual supplementation on an industrial-farm scale would require a large amount of time and manpower.
Probiotics are beneficial microbes, mostly bacteria, that are administered in a prepared form or directly in a live form to poultry or other animals (Fuller 1992). Probiotic bacteria must remain viable to exert their functions (Harimurti and Hadisaputro 2015). Encapsulation protects the bacteria from external damaging factors (Kailasapathy 2002; Soukoulis et al. 2014), and thus maintains their viability and functional activities. In the context of producing probiotic feed supplements for the large-scale poultry industry, encapsulation is required to maintain cell viability during processing and storage. Spray drying is presently one of the most feasible and frequently used methods for bacterial cell encapsulation. This method is rapid, costeffective, and reproducible. Additionally, the method facilitates size control and is suitable for industrial-scale applications (Burgain et al. 2011; Serna-Cock and Vallejo-Castillo 2013; Mutukumira et al. 2014; Soukoulis et al. 2014). In a previous in vitro study, encapsulated probiotics inhibited the growth of Salmonella enteritidis and Escherichia coli (unpublished data). Therefore, we elucidated the effects of feed supplementation with encapsulated probiotics on the performance of chickens.

\section{MATERIALS AND METHODS}

\subsection{Bacterial strains and growth media}

The following indigenous $\mathrm{LAB}$ strains were previously isolated from the gastrointestinal tracts of native Indonesian chickens: Lactobacillus murinus strain Ar-3, Streptococ- 
cus thermophilus strain Kp-2, and Pediococcus acidilactici strain Kd-6 (Harimurti et al. 2007). Maltodextrin with a dextrose equivalent of 10 and skim milk powder (SMP) were used as carriers during spray drying.

Peptone glucose yeast broth (PGYB) and PGY agar (PGYA) were used for bacterial propagation and cell enumeration, respectively. Coconut water and bean sprout extract, a bacterial enrichment medium, was prepared as follows: $450 \mathrm{~g}$ bean sprouts were chopped, mixed with 900 $\mathrm{mL}$ coconut water, sterilized at $121^{\circ} \mathrm{C}$ for $5 \mathrm{~min}$, and filtered. Coconut water, sterilized at $121^{\circ} \mathrm{C}$ for $15 \mathrm{~min}$, was added to the solution to a final volume of $1,800 \mathrm{~mL}$.

\subsection{Probiotic starter preparation and biomass production}

Each probiotic strain (L. murinus strain Ar-3, S. thermophiles strain $\mathrm{Kp}-2$, and $\mathrm{P}$. acidilactici strain $\mathrm{Kd}-6$ ) was inoculated in $5 \mathrm{~mL}$ PGYB and incubated for $24 \mathrm{~h}$ at $37^{\circ} \mathrm{C}$. The cells were then harvested and recultivated in $10 \mathrm{~mL}$ PGYB for an additional $24 \mathrm{~h}$ at $37^{\circ} \mathrm{C}$. A subsequent culture was grown in $30 \mathrm{~mL}$ coconut water and bean sprout extract and incubated for $24 \mathrm{~h}$ at $37^{\circ} \mathrm{C}$. Thereafter, $30-\mathrm{mL}$ cell suspension was harvested, transferred into $1,800 \mathrm{~mL}$ coconut water and bean sprout extract, and incubated for another $18 \mathrm{~h}$ at $37^{\circ} \mathrm{C}$.

The final cell suspension was transferred into sterile 1-L centrifuge bottles and centrifuged at $1350 \times \mathrm{g}$ for $30 \mathrm{~min}$ at $4^{\circ} \mathrm{C}$. After discarding the supernatant, sterile peptone-buffered saline was added to each pellet and centrifuged. Each harvested pellet was mixed with $10 \%(\mathrm{w} / \mathrm{v})$ skim milk (SM) and $2 \%(\mathrm{w} / \mathrm{v})$ sucrose $(5: 1, \mathrm{v} / \mathrm{v}$ ratio) and stored overnight at $4^{\circ} \mathrm{C}$ before encapsulation.

\subsection{Bacterial cell encapsulation and powder evaluation}

Maltodextrin and SMP solutions were prepared in distilled water $(20 \%, \mathrm{w} / \mathrm{v}$, each solution) by gentle stirring. The solutions were then sterilized at $121^{\circ} \mathrm{C}$ for $15 \mathrm{~min}$ and $115^{\circ} \mathrm{C}$ for $10 \mathrm{~min}$, respectively. Subsequently, they were aseptically mixed together with bacterial pellets for $1 \mathrm{~h}$ at room temperature. Initial cell viability was counted before spray drying. The mixed solution, comprising cell biomass and carriers, was spray dried using a small-scale spray dryer with inlet and outlet temperatures of $180^{\circ} \mathrm{C}$ and $60^{\circ} \mathrm{C}$, respectively. The spray-dried powder was collected in a sterile plastic clip and stored under aerobic conditions at room temperature $\left(30^{\circ} \mathrm{C}\right)$ for 7 weeks. The collected powder was then subjected to cell viability, moisture content, and water activity analyses accompanied with a scanning electron microscopy (SEM) evaluation of cell shape and morphology.

Cell viability was analyzed after preparation (day 0 ) and during storage. The powders were suspended and diluted in $0.85 \% \mathrm{NaCl}$ solution and constantly mixed by shaking for $10 \mathrm{~min}$ at room temperature to ensure complete dissolution. The solutions were then serially diluted, plated on PGYA, and incubated for $48 \mathrm{~h}$ at $37^{\circ} \mathrm{C}$ under aerobic conditions. The observed colonies were counted, and the $\mathrm{CFU} / \mathrm{g}$ was calculated. The viability of encapsulated probiotic bacteria was determined on days $0,3,7,14,21,28,35,42$, and 49 of storage and calculated according to Equation 1.

$$
\operatorname{Viability}(\%)=100 \times \frac{N_{x}}{N_{0}}
$$

where $N_{0}$ is the cell viability after preparation (day 0 ) and $N_{x}$ is the cell viability during storage ( $x$ denotes the number of days in storage). Furthermore, cell viability was evaluated after the encapsulated probiotics were exposed to temperatures between $80^{\circ} \mathrm{C}$ and $85^{\circ} \mathrm{C}$ for 15 or $30 \mathrm{~s}$. Serially diluted samples $(1 \mathrm{~mL})$ were pour plated on PGYA before and after high-temperature exposure.

The moisture content of the encapsulated probiotics was measured using a vacuum oven method (Soukoulis et al. 2014) by exposing the powders at $100^{\circ} \mathrm{C}$ for $4 \mathrm{~h}$. The water activity was measured at $25^{\circ} \mathrm{C}$ using a Pawkit water activity meter. The shape and morphology of the powders were observed using SEM, and images were recorded at an accelerating voltage of $10 \mathrm{kV}$.

\subsection{Animal and feed formulation}

This experiment was performed at the poultry research facility of the Faculty of Animal Science of Universitas Gadjah Mada, Indonesia, in compliance with the Guide for the Care and Use of Laboratory Animals. A total of 48 one-day-old chicks, vaccinated against Marek's disease and infectious bursal disease, were used. The chicks were randomly categorized into four treatment groups of four chickens each: T0, T1, T2, and T3. The T0 group was raised without probiotics, whereas the T1, T2, and T3 groups were provided feed supplemented with probiotics at concentrations of $0.5,1.0$, and $1.5 \mathrm{~g} / \mathrm{kg}$, respectively. All treatments were performed in triplicates for $21 \mathrm{~d}$. The broiler chicken diet, mainly comprising corn and soybean meal without antibiotics, was formulated to meet the National Research Council's (National Research Council 1994) recommendations. This diet contained $22.29 \%$ crude protein and 3,074.90 kcal $/ \mathrm{kg}$ metabolizable energy. In addition, it contained $1.15 \%(\mathrm{w} / \mathrm{w})$ calcium, $0.63 \%(\mathrm{w} / \mathrm{w})$ available phosphorus, $0.55 \%(\mathrm{w} / \mathrm{w}) \mathrm{me}-$ thionine, $1.23 \%(\mathrm{w} / \mathrm{w})$ lysine $\mathrm{HCl}$, and $0.24 \%(\mathrm{w} / \mathrm{w})$ tryptophan. Feed and drinking water were provided ad libitum. The growth performance of chickens was evaluated by recording the weekly feed consumption, body weight gain, live weight, and feed conversion ratio.

\subsection{Sample collection}

At the end of the starter phase, three birds from each treatment group were randomly euthanized and sacrificed by severing the jugular vein. The intestines were immediately harvested, and the length and weight of the intestinal tract (duodenum, jejunum, ileum, and cecum) were measured. One bird from each treatment group was randomly sacrificed at the third week of age for histological analysis of the intestinal structure. Small sections $(2 \mathrm{~cm})$ of the duodenum, jejunum, and ileum were excised and immediately washed with $0.85 \% \mathrm{NaCl}$ solution. Each sample was placed in $10 \%$ formalin buffer and fixed for $48 \mathrm{~h}$ before histological processing.

\subsection{Histology}

The tissue samples were dehydrated using a series of increasing alcohol concentrations (30\%, 50\%, 70\%, 80\%, $90 \%, 95 \%$, and $100 \%$ ), and embedded in paraffin wax. A microtome was used to obtain $5-\mu \mathrm{m}$ sections, which were placed on glass slides for hematoxylin and eosin staining. The histological sections were observed using a light microscope.

\subsection{Statistical analysis}

Data were analyzed using one-way analysis of variance, followed by Duncan's new multiple range test, and viability data collected before and after spray drying were analyzed using t-test. Differences were considered to be significant at $p<0.05$. 


\section{RESULTS}

\subsection{Cell viability}

Before spray drying, cell viability was $10^{8}-10^{10} \mathrm{CFU} / \mathrm{g}$. Log reductions of one- to two-fold were observed after spray drying (Table 1), suggesting that the percent viability of all samples exceeded $80 \%$. The total cell viability of all encapsulated bacterial species weekly decreased during storage (Figure 1). A combination of three and one species (P. acidilactici strain $\mathrm{Kd}-6$ ) exhibited viability rates of up to $70 \%$ during the first four weeks of storage, followed by decreases after seven weeks. After four weeks of storage, S. thermophilus strain Kp-2 and L. murinus strain Ar-3 had viabilities of $63 \%$ and $40 \%$, respectively. Moreover, the viability of both strains decreased further after seven weeks.

The decrease in bacterial cell viability during feed processing is likely caused by heat treatments. Accordingly, encapsulation should protect bacterial cells and promote survival. In the present study, probiotic cells were encapsulated using a mixture of maltodextrin and SMP and collected as described in the Materials and Methods section. The survival ability of encapsulated cells was then measured in response to exposure to temperatures of $80-85^{\circ} \mathrm{C}$. All strains, except L. murinus strain Ar-3, exhibited post exposure viability rates of greater than $80 \%$ (Table 2). S. thermophilus strain Kp-2 and P. acidilactici strain Kd-6 could maintain the viability rates as high as $80 \%$ after exposure to temperatures of $80-85^{\circ} \mathrm{C}$ for $30 \mathrm{~s}$. Notably, there were no differences $(p>0.05)$ in the survival rate among four samples exposed to high temperatures for $45 \mathrm{~s}$ (data not shown). Thus, a combination of maltodextrin and SMP yielded good cell protection against heat exposure for 15 or $30 \mathrm{~s}$ (Table 2). After 15 s, P. acidilactici strain Kd-6 was most persistent compared with L. murinus strain Ar-3 and S. thermophilus strain Kp-2. After $30 \mathrm{~s}$, S. thermophilus strain Kp-2 and P. acidilactici strain $\mathrm{Kd}-6$ had higher survival rates than that observed in L. murinus strain Ar-3.

\subsection{Moisture content, water activity, and SEM of the en- capsulated probiotics}

The samples significantly differed with respect to moisture content and water activity (Table 3). The highest moisture content among the encapsulated probiotics (3.99\%) was recorded for P. acidilactici strain Kd-6, whereas the lowest $(3.60 \%)$ was reported for the combined species. The powder containing P. acidilactici strain Kd-6 had the highest water activity $(0.20)$, whereas that containing $S$. thermophilus strain Kp-2 had the lowest value at 0.17 . The high water activity of P. acidilactici strain Kd-6 was in line with the high moisture content.

The morphologies of the encapsulated probiotics of spray-dried powders visualized using SEM are shown in Figure 2. These particles had irregular morphological shapes, including deflated, flat, ball-like, and spherical, and their sizes ranged from 2.56 to $27.00 \mu \mathrm{m}$.

\subsection{Performance of chickens}

Based on the data presented in Tables 1-3 and Figure 1, the combined probiotic culture was selected to analyze the effect of probiotic feed supplementation on the performance of chickens. Although probiotic powder supplementation did not affect feed consumption between the treatments groups, it led to significant increases in body weight gain, live weight, and feed conversion ratio (Table 4). Regarding the intestinal segments (e.g., duodenum, jejunum, and
TABLE 1. Viabilities of encapsulated probiotics before and after spray drying (log CFU/g).

\begin{tabular}{lcccc}
\hline \multirow{2}{*}{ Time } & \multicolumn{4}{c}{$\log$ CFU/g } \\
\cline { 2 - 5 } & ${\text { L. } \text { murinus }^{\mathrm{a}}}$ & S. thermophilus $^{\mathrm{a}}$ & P. $^{\text {acidilactici }}{ }^{\mathrm{b}}$ & Mixture $^{\mathrm{a}}$ \\
\hline Before & $9.53 \pm 0.21$ & $9.30 \pm 0.30$ & $8.52 \pm 0.45$ & $10.10 \pm 0.17$ \\
After & $8.00 \pm 0.00$ & $8.42 \pm 0.10$ & $8.00 \pm 0.00$ & $9.10 \pm 0.17$ \\
\hline
\end{tabular}

a Significant $(p<0.05)$, ${ }^{\mathrm{b}}$ Nonsignificant.

TABLE 2. Viability percentages of encapsulated probiotics after 15 or $30 \mathrm{~s}$ exposure to $80-85^{\circ} \mathrm{C}(\%)$.

\begin{tabular}{lrrrc}
\hline Time & L. murinus & S. thermophilus & P. acidilactici & Mixture \\
\hline $15 \mathrm{~s}$ & $92.78^{\mathrm{a}, \mathrm{y}} \pm 3.02$ & $87.31^{\mathrm{z}} \pm 4.56$ & $98.43^{\mathrm{a}, \mathrm{x}} \pm 0.74$ & $97.13^{\mathrm{a}, \mathrm{xy}} \pm 0.87$ \\
$30 \mathrm{~s}$ & $77.92^{\mathrm{b}, \mathrm{z}} \pm 1.76$ & $85.05^{\mathrm{xy}} \pm 0.28$ & $81.81^{\mathrm{b}, \mathrm{y}} \pm 4.71$ & $87.05^{\mathrm{c}, \mathrm{x}} \pm 0.53$
\end{tabular}

$x, y, z$ Mean values with different superscripts in the same row differ significantly $(p<0.05)$.

$a, b, c$ Mean values with different superscripts in the same column differ significantly $(p<0.05)$.

TABLE 3. Moisture content and water activity of encapsulated probiotics.

\begin{tabular}{lcc}
\hline Probiotic & Moisture content (\%) & Water activity \\
\hline L. murinus & $3.77^{\mathrm{c}} \pm 0.05$ & $0.19^{\mathrm{a}} \pm 0.01$ \\
S. thermophiles & $3.80^{\mathrm{bc}} \pm 0.02$ & $0.17^{\mathrm{c}} \pm 0.00$ \\
P. acidilactici & $3.99^{\mathrm{ab}} \pm 0.13$ & $0.20^{\mathrm{a}} \pm 0.01$ \\
Combined species & $3.60^{\mathrm{c}} \pm 0.12$ & $0.19^{\mathrm{a}} \pm 0.00$ \\
Control (without probiotic) & $4.10^{\mathrm{a}} \pm 0.15$ & $0.18^{\mathrm{b}} \pm 0.00$ \\
\hline
\end{tabular}

Control: a mixture of maltodextrin and SMP without probiotic addition. a,b,c Mean values with different superscripts in the same column differ significantly $(p<0.05)$.

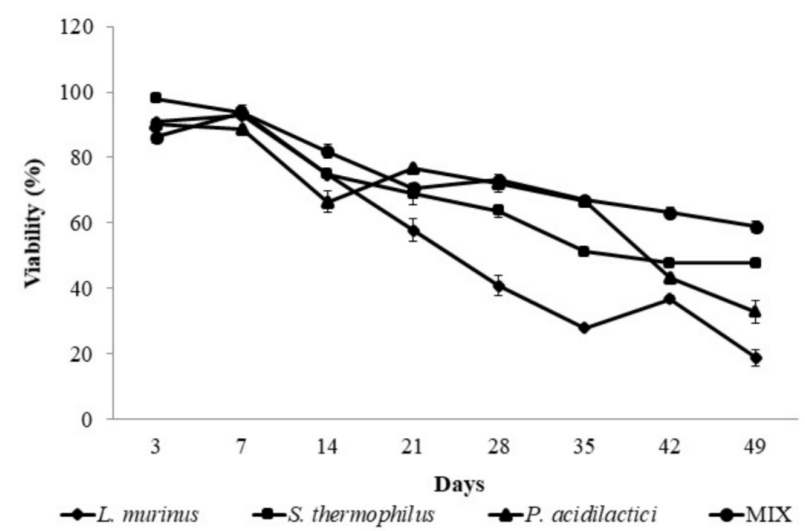

FIGURE 1. Cell viability rates of encapsulated probiotics stored at $30^{\circ} \mathrm{C}$ for 49 days. MIX: mixture.

ileum), only the cecum length significantly different among the treatment groups, and the weights of the jejunum and cecum were significantly different (Table 5). The analysis of intestinal histology indicated a greater villus density in the treatment groups than that in the control group, even at the lowest level of supplementation $(0.5 \mathrm{~g} / \mathrm{kg}$ feed; Figure $3)$. The ileum clearly contained shorter villi in the control group than that in the treatment groups.

\section{DISCUSSION}

SMP contains lactose and proteins, which minimize the cellular membrane damage during spray drying. According to the water replacement theory, lactose and milk proteins protect cells by interacting with the polar head groups of membrane phospholipids (Crowe et al. 1998; van Oss 2008; 
Soukoulis et al. 2014). A previous study reported that samples prepared with a mixture of maltodextrin/SMP (1:1) had high viable cell count (8 log CFU/g) after four weeks of storage at $30^{\circ} \mathrm{C}$ (Mutukumira et al. 2014), including temperature, moisture content, and oxidative stress (Abd-Talib et al. 2013). Because the encapsulated probiotics in the present study were stored at $30^{\circ} \mathrm{C}$ and under aerobic conditions, exposure to oxygen might have caused oxidative stress in the cells, triggering cell death and a decrease in viability.

Feed manufacturers commonly use heat and moisture to produce dry meal. In Indonesia, feed mills routinely operate at $85-88^{\circ} \mathrm{C}$ to generate dry feed (Muttaqin 2005). In the present study, viability rates of greater than $80 \%$ were noted after exposure to temperatures of $80-85^{\circ} \mathrm{C}$ in spraydried probiotics, except for L. murinus strain Ar-3. This finding agrees with a previous study, wherein P. acidilactici strain Kd-6 and S. thermophilus strain Kp-2 were thermotolerant under drought and high-temperature (up to $50^{\circ} \mathrm{C}$ ) conditions (Abd-Talib et al. 2013). Another study reported viability rates of greater than $90 \%$ for Bacillus subtilis, a heat resistant, spore-forming bacterial strain, exposed to temperatures of $85-90^{\circ} \mathrm{C}$ (Setlow 2006).

The moisture content data met the acceptable limit of greater than $4 \%$ for a dried product (Gharsallaoui et al.
2007). The water activity is a measure of water molecules available in a "free" form. Bound water is the water molecules involved in hydrating hydrophilic molecules and dissolving solutes; it does not contribute to the water activity (Setlow 2006). A previous study found that the three tested strains had different cell surface hydrophobicities: L. murinus strain Ar-3 had a 93.56\% hydrophilic cell surface, whereasS. thermophilus strain Kp-2 and P. acidilactici strain Kd-6 had values of $96.61 \%$ and $96.28 \%$, respectively (Harimurti 2011). This result supports the high moisture content observed in S. thermophilus strain Kp-2 and P. acidilactici strain Kd-6 in the present study.

A study on microcapsule powder reported a similar size range of 1-25 $\mu \mathrm{m}$ (Mutukumira et al. 2014). The strong ability of the maltodextrin/SM matrix to preserve cell viability (Table 2) might be attributable to its good encapsulating properties (Figure 2). Maltodextrin alone exhibited poor interfacial properties and would require chemical modification to improve the surface activity. Conversely, SMP is amphiphilic and exhibits the physicochemical and functional properties required to encapsulate materials with hydrophobic cores. Moreover, protein compounds, such as sodium caseinate, soy protein isolate, and whey protein concentrate and isolate, may exhibit good microencapsulating properties (Soukoulis et al. 2014).

TABLE 4. Effects of supplementation with microencapsulated indigenous probiotic lactic acid bacteria on performance parameters.

\begin{tabular}{|c|c|c|c|c|}
\hline Criteria & T0 (control) & $\mathrm{T} 1$ (0.5 g probiotics/kg feed) & T2 (1.0 g probiotics/kg feed) & T3 (1.5 g probiotics/ kg feed) \\
\hline \multicolumn{5}{|c|}{ Feed consumption, g/bird } \\
\hline Week 1 & $108.71 \pm 4.66$ & $112.91 \pm 2.48$ & $107.81 \pm 1.31$ & $110.70 \pm 1.57$ \\
\hline Week 2 & $230.27 \pm 21.57$ & $215.70 \pm 5.90$ & $226.77 \pm 12.72$ & $240.26 \pm 5.52$ \\
\hline Week 3 & $238.60 \pm 30.41$ & $207.65 \pm 12.68$ & $242.27 \pm 6.65$ & $235.98 \pm 28.52$ \\
\hline Starter phase & $577.59 \pm 54.46$ & $536.26 \pm 19.11$ & $576.85 \pm 17.44$ & $586.94 \pm 33.20$ \\
\hline \multicolumn{5}{|c|}{ Body weight gain (g/bird) } \\
\hline Week 1 & $76.83^{b} \pm 5.67$ & $96.17^{\mathrm{a}} \pm 5.44$ & $90.08^{a} \pm 4.50$ & $92.75^{\mathrm{a}} \pm 3.53$ \\
\hline Week 2 & $147.67^{b} \pm 15.14$ & $174.83^{a} \pm 9.77$ & $175.25^{\mathrm{a}} \pm 4.98$ & $185.67^{\mathrm{a}} \pm 15.18$ \\
\hline Week 3 & $101.42^{c} \pm 3.36$ & $111.00^{b c} \pm 22.66$ & $148.42^{\mathrm{ab}} \pm 8.31$ & $172.33^{\mathrm{a}} \pm 40.84$ \\
\hline Starter phase & $324.00^{b} \pm 21.69$ & $364.75^{\mathrm{ab}} \pm 34.95$ & $402.50^{\mathrm{a}} \pm 4.27$ & $400.17^{\mathrm{a}} \pm 37.50$ \\
\hline \multicolumn{5}{|c|}{ Live weight (g/bird) } \\
\hline Week 1 & $119.58^{b} \pm 6.64$ & $140.08^{\mathrm{a}} \pm 5.57$ & $133.00^{\mathrm{a}} \pm 5.11$ & $137.17^{\mathrm{a}} \pm 5.15$ \\
\hline Week 2 & $275.75^{b} \pm 17.18$ & $312.00^{a} \pm 15.16$ & $306.50^{\mathrm{a}} \pm 6.34$ & $317.17^{\mathrm{a}} \pm 12.25$ \\
\hline Week 3 & $366.75^{b} \pm 23.01$ & $408.67^{\mathrm{ab}} \pm 35.50$ & $445.42^{\mathrm{a}} \pm 5.95$ & $444.58^{\mathrm{a}} \pm 35.75$ \\
\hline Starter phase & $366.75^{b} \pm 23.01$ & $408.67^{a b} \pm 35.50$ & $445.42^{\mathrm{a}} \pm 5.95$ & $444.58^{\mathrm{a}} \pm 35.75$ \\
\hline \multicolumn{5}{|c|}{ Feed conversion ratio (g/g) } \\
\hline Week 1 & $1.43^{\mathrm{a}} \pm 0.09$ & $1.19^{b} \pm 0.08$ & $1.20^{\mathrm{b}} \pm 0.08$ & $1.20^{b} \pm 0.03$ \\
\hline Week 2 & $1.57^{\mathrm{a}} \pm 0.09$ & $1.24^{b} \pm 0.04$ & $1.30^{b} \pm 0.05$ & $1.30^{\mathrm{b}} \pm 0.12$ \\
\hline Week 3 & $2.54^{\mathrm{a}} \pm 0.45$ & $2.06^{a b} \pm 0.16$ & $1.68^{b} \pm 0.13$ & $1.59^{b} \pm 0.25$ \\
\hline Starter phase & $1.8^{\mathrm{a}} \pm 0.07$ & $1.49^{b} \pm 0.08$ & $1.44^{b} \pm 0.05$ & $1.48^{\mathrm{b}} \pm 0.07$ \\
\hline
\end{tabular}

$a, b, c$ Mean values with different superscripts in the same row differ significantly $(p<0.05)$.

TABLE 5. Effect of supplemented microencapsulated indigenous probiotic lactic acid bacteria on intestinal length (cm) and weight (g).

\begin{tabular}{|c|c|c|c|c|c|c|c|c|}
\hline \multirow[t]{2}{*}{ Treatment } & \multicolumn{2}{|c|}{ Duodenum } & \multicolumn{2}{|c|}{ Jejunum } & \multicolumn{2}{|c|}{ Ileum } & \multicolumn{2}{|c|}{ Cecum } \\
\hline & Length $^{\text {ns }}$ & Weight $^{\text {ns }}$ & Length $^{\text {ns }}$ & Weight & Length $^{\text {ns }}$ & Weight $^{\text {ns }}$ & Length & Weight \\
\hline T0 (control) & $18.50 \pm 1.32$ & $2.27 \pm 0.43$ & $41.33 \pm 1.04$ & $4.10 b \pm 0.53$ & $40.67 \pm 3.78$ & $2.95 \pm 0.45$ & $10.45^{\mathrm{ab}} \pm 0.64$ & $1.30^{b} \pm 0.16$ \\
\hline $\mathrm{T} 1$ (0.5 g/ kg feed) & $18.77 \pm 2.58$ & $2.09 \pm 0.49$ & $45.80 \pm 4.70$ & $4.01^{b} \pm 0.80$ & $43.43 \pm 0.51$ & $2.59 \pm 0.47$ & $9.22^{b} \pm 1.09$ & $1.12^{b} \pm 0.24$ \\
\hline T2 (1.0 g/ kg feed) & $17.17 \pm 0.76$ & $2.46 \pm 0.29$ & $46.00 \pm 2.00$ & $5.16^{\mathrm{ab}} \pm 0.84$ & $43.63 \pm 2.90$ & $3.40 \pm 0.50$ & $9.72^{b} \pm 0.60$ & $1.49^{\mathrm{ab}} \pm 0.03$ \\
\hline T3 (1.5 g/ kg feed) & $20.67 \pm 1.04$ & $2.74 \pm 0.54$ & $46.73 \pm 5.37$ & $5.65^{\mathrm{a}} \pm 0.42$ & $43.27 \pm 3.16$ & $4.07 \pm 0.85$ & $11.93^{\mathrm{a}} \pm 1.41$ & $1.88^{\mathrm{a}} \pm 0.41$ \\
\hline
\end{tabular}

a,b,c Mean values with different superscripts in the same column differ significantly $(p<0.05)$.

${ }^{n s}$ Nonsignificant 


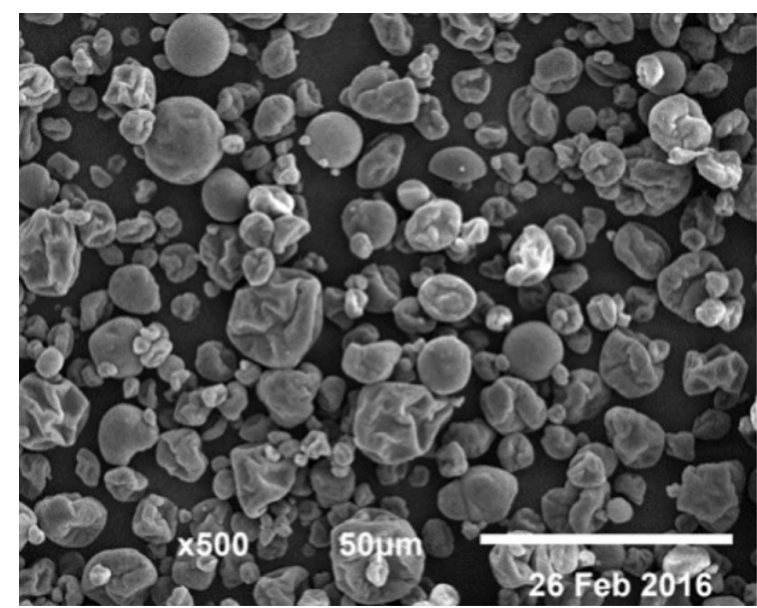

(a)

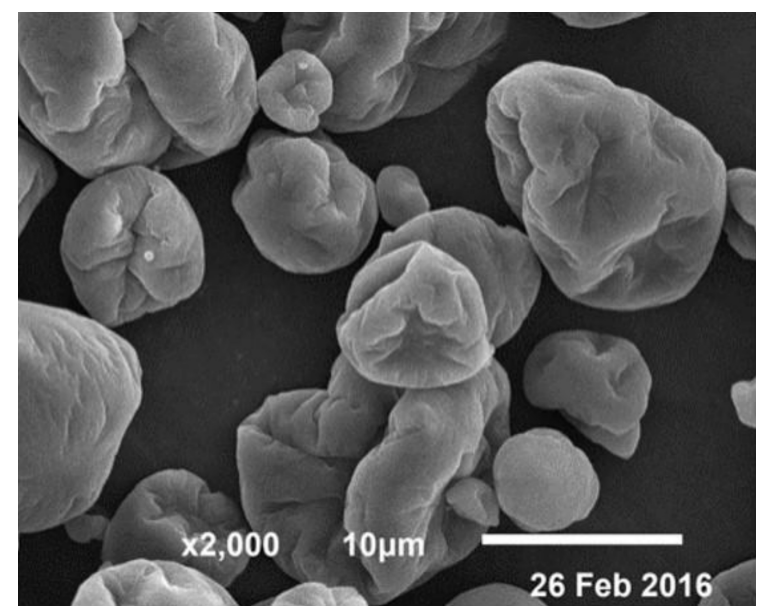

(b)

FIGURE 2. SEM of spray-dried microcapsule powders containing a mixed culture of probiotics. Scale bars, (a) $50 \mu \mathrm{m}$ and (b) $10 \mu \mathrm{m}$.

In the present study, probiotic powder supplementation led to a significant increase in body weight gain, live weight, and feed conversion ratio, although it did not affect the feed consumption between the treatment groups. This finding is in agreement with that of previous studies (Harimurti et al. 2012; Amerah et al. 2013; Harimurti and Hadisaputro 2014). The complex metabolites produced by complementary probiotic strains may act synergistically to support health (Ray 1996). A study reported that oral probiotic supplementation increased the concentration of short-chain fatty acids (e.g., propionic acid and butyric acid) in broiler chickens (Harimurti and Hadisaputro 2014). Although LAB do not directly produce butyric acid, their consumption indirectly leads to increased butyric acid concentration in the digestive tract, a process known as crossfeeding. In vitro, lactic acid produced by Bifidobacterium adolescentis is used by Eubacterium halii and Anaerostipes caccae (in coculture) to produce large amounts of butyric acid (Anuradha and Rajeshwari 2005), which is required by the intestinal epithelial cells to stimulate the proliferation of normal epithelium and maintain mucosal barrier defenses (Harimurti et al. 2012). This absorptive function might be reflected by the ratio of villi height to crypt depth in the small intestine.

\section{CONCLUSIONS}

In conclusion, the tested maltodextrin/SMP mixture exhibited good encapsulating properties that protected probi-

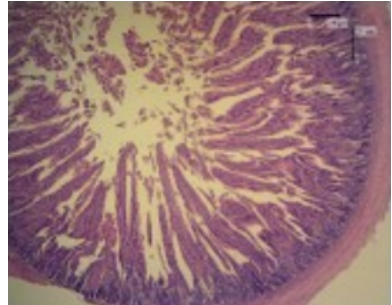

(a)

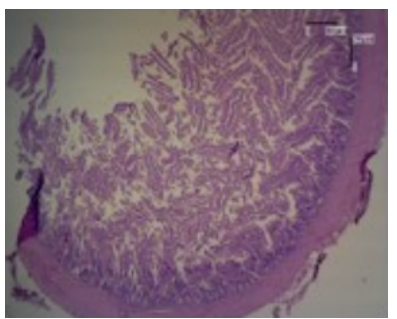

(c)

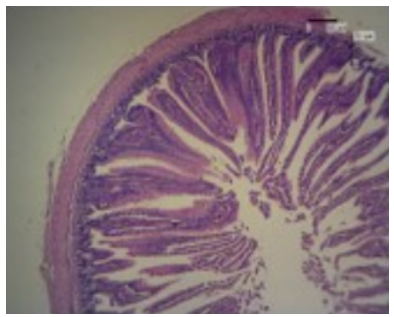

(e)

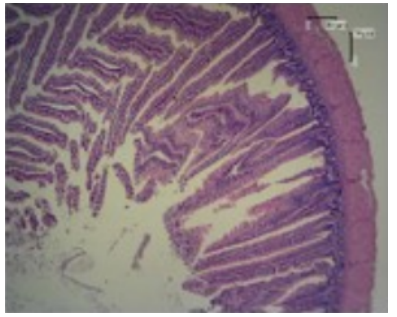

(g)

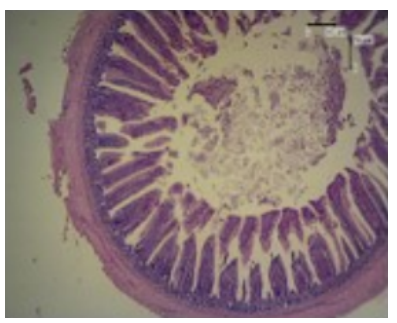

(i)

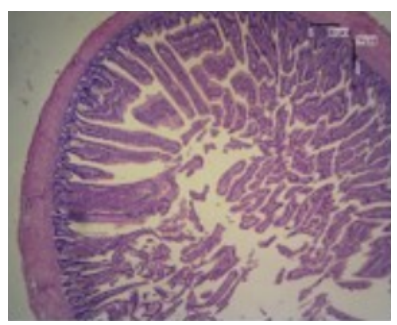

(k)

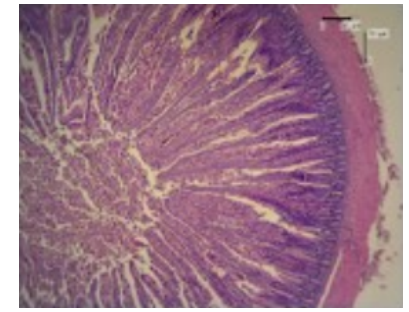

(b)

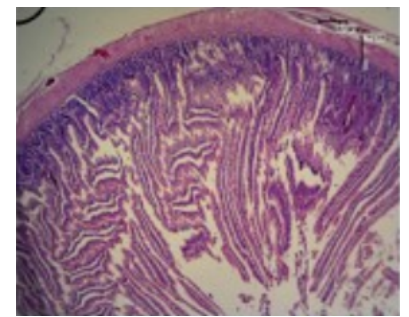

(d)

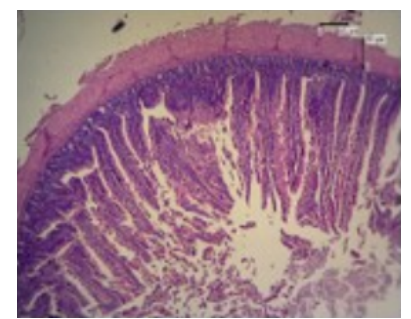

(f)

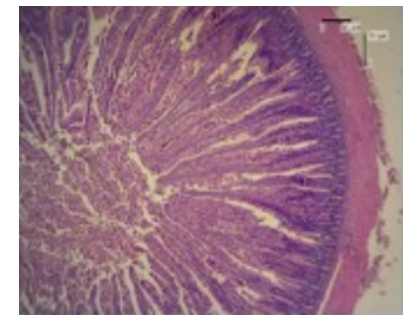

(h)

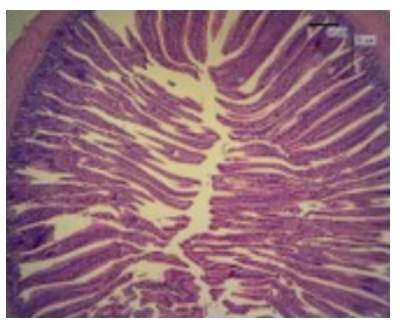

(j)

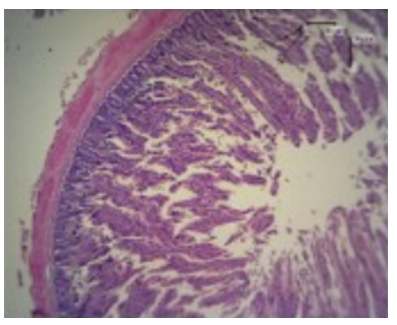

(l)
FIGURE 3. Histologic analysis of duodenal (a-d), jejunal (e-h), and ileal tissues (i-l) from broiler chickens during the starter phase. Scale bars, $20 \mu \mathrm{m}$.

otic cells during heat treatment and maintained cell viability during storage. Supplementation with the encapsulated probiotics improved chickens' live weights, body weight gain, and feed conversion ratios as well as promoted better 
villus development, which could increase nutrient absorption. Therefore, encapsulated probiotic supplementation could be used as an alternative chicken feed supplement to improve the growth performance.

\section{ACKNOWLEDGMENTS}

The authors acknowledge all the poultry laboratory assistants of the Faculty of Animal Science, Universitas Gadjah Mada, for their roles in study execution. This study was part of Ms. Monica Sonia Indri Pradipta's thesis work at the Faculty of Animal Science, Universitas Gadjah Mada.

\section{COMPETING INTERESTS}

One of the authors, Widodo, also serves as the Editor-inChief of AJSTD. To avoid potential conflicts of interest, they were recused from the review and final decision processes.

\section{REFERENCES}

Abd-Talib N, Mohd-Setapar SH, Khamis AK, Nian-Yian L, Aziz R. 2013. Survival of encapsulated probiotics through spray drying and non-refrigerated storage for animal feeds application. Agric Sci. 4:78-83. doi:10.423 6/as.2013.45b015.

Amerah AM, Quiles M, Medel P, Sanchez J, Lehtinen MJ, Gracia MI. 2013. Effect of pelleting temperature and probiotic supplementation on growth performance and immune function of broilers fed maize/soy-based diets. Anim Feed Sci Technol. 180(1-4):55-63. doi: 10.1016/j.anifeedsci.2013.01.002.

Anuradha S, Rajeshwari K. 2005. Probiotics in health and disease. J Indian Acad Clin Med. 6:67-72.

Arsi K, Donoghue AM, Woo-Ming A, Blore PJ, Donoghue DJ. 2015. The efficacy of selected probiotic and prebiotic combinations in reducing Campylobacter colonization in broiler chickens. J Appl Poult Res. 24(3):327-334. doi: 10.3382/japr/pfv032.

Burgain J, Gaiani C, Linder M, Scher J. 2011. Encapsulation of probiotic living cells: From laboratory scale to industrial applications. J Food Eng. 104(4):467-483. doi: 10.1016/j.jfoodeng.2010.12.031.

Cogliani C, Goossens H, Greko C. 2011. Restricting antimicrobial use in food animals: lessons from Europe. Microbe Mag. 6(6):274-279. doi:10.1128/microbe.6.274.1.

Crowe JH, Carpenter JM, Crowe LM. 1998. The role of vitrification in anhydrobiosis. Annu Rev Physiol. 60(1):73-103. doi:10.1146/annurev.physiol.60.1.73.

Fuller R. 1992. History and development of probiotics. In: Probiotics. Dordrecht: Springer International Publishing. p. 1-8. doi:10.1007/978-94-011-2364-8_1.

Gharsallaoui A, Roudaut G, Chambin O, Voilley A, Saurel R. 2007. Applications of spray-drying in microencapsulation of food ingredients: An overview. Food Res Int. 40(9):1107-1121. doi:10.1016/j.foodres.2007.07.004.

Harimurti S. 2009. Study of competitive exclusion of Salmonella pullorum by probiotic strains in the broiler chickens. International Seminar of 5th Asian Conference on Lactic Acid Bacteria: Microbes in Disease Prevention and Treatment, Singapore.

Harimurti S. 2011. Indigenous lactic acid bacteria probiotics: its influence on biological expressions of broiler chickens [PhD thesis]. [Yogyakarta]: Universitas Gadjah Mada.

Harimurti S, Hadisaputro W. 2014. Effect of indigenous probiotics lactic acid bacteria on performance, intesti- nal length and weight of internal organs of broiler chicken. International Conference on Beneficial Microbes, Penang, Malaysia. p. 179-181.

Harimurti S, Hadisaputro W. 2015. Probiotics in poultry. In: Liong MT, Steinbüchel A, editors. Beneficial microorganisms in agriculture, aquaculture and other areas. Springer International Publishing. p. 1-19. doi:10.100 7/978-3-319-23183-9_1.

Harimurti S, Huda M, Kristiani AD. 2013. The dynamics of indigenous lactic acid bacteria probiotics on carcass yield, abdominal fat and intestinal morphology of broilers. Proceeding of the 3rd AINI International Seminar. Padang: Indonesian Association of Nutrition And Feed Science. p. 185-188.

Harimurti S, Nasroedin N, Kurniasih. 2007. Lactic acid bacteria isolated from the gastro-intestinal tract of chicken: potential use as probiotic. J Anim Prod. 9:8291.

Harimurti S, Rahayu ES, Kurniasih. 2012. The impact of indigenous lactic acid bacteria on the ability to adhere on chicken ileal epithelial cells and productivity performance of the broiler. The 15th Asian Australasian Animal Production Congress, Bangkok. p. 1314-1318.

Kailasapathy K. 2002. Microencapsulation of probiotic bacteria: technology and potential applications. Curr Issues Intest Microbiol. 3(2):39-48.

Muttaqin A. 2005. Study of pelleting lactic acid bacteria probiotics as feed supplement on chickens [PhD thesis]. [Yogyakarta]: Universitas Gadjah Mada.

Mutukumira AN, Ang V, Lee SJ. 2014. Viability and properties of spray-dried Lactobacillus casei-01. Proceedings of the International Conference on Beneficial Microbes, Penang, Malaysia.

National Research Council. 1994. Nutrient requirements of poultry. 9th edition. Washington, DC: The National Academies Press. doi:10.17226/2114.

Ray B. 1996. Fundamental food microbiology. 1st edition. Boca Raton: CRC Press.

Schneitz C, Koivunen E, Tuunainen P, Valaja J. 2016. The effects of a competitive exclusion product and two probiotics on Salmonella colonization and nutrient digestibility in broiler chickens. J Appl Poult Res. 25(3):396-406. doi:10.3382/japr/pfw025.

Serna-Cock L, Vallejo-Castillo V. 2013. Probiotic encapsulation. African J Microbiol Res. 7(40):4743-4753. doi: 10.5897/ajmr2013.5718.

Setlow P. 2006. Spores of Bacillus subtilis: their resistance to and killing by radiation, heat and chemicals. J Appl Microbiol. 101(3):514-525. doi:10.1111/j.1365-2672.2005 .02736.x.

Soukoulis C, Behboudi-Jobbehdar S, Yonekura L, Parmenter C, Fisk I. 2014. Impact of milk protein type on the viability and storage stability of microencapsulated Lactobacillus acidophilus NCIMB 701748 using spray drying. Food Bioprocess Technol. 7(5):1255-1268. doi:10.1007/s11947-013-1120-x.

van Immerseel F, de Zutter L, Houf K, Pasmans F, Haeserbrouck F, Ducatelle R. 2009. Strategies to control Salmonella in the broiler production chain. World's Poult Sci J. 65(3):367-392. doi:10.1017/s004393390 9000270.

van Oss CJ. 2008. The extended DLVO theory. In: van Oss CJ, editor. The properties of water and their role in colloidal and biological systems. Amsterdam: Academic Press. p. 31-48. doi:10.1016/S1573-4285(08)00203-2. 